\title{
Modeling and Optimization of Steel Machinability with Genetic Programming: Industrial Study
}

\author{
Miha Kovačič 1,2,3,*, Shpetim Salihu ${ }^{4}$, Gašper Gantar ${ }^{3,5}$ and Uroš Župerl ${ }^{4}$ \\ 1 ŠTORE STEEL, d.o.o., Research and Development, 3220 Štore, Slovenia \\ 2 Laboratory for Fluid Dynamics and Thermodynamics, University of Ljubljana, Faculty of Mechanical \\ Engineering, 1000 Ljubljana, Slovenia \\ 3 College of Industrial Engineering, 3000 Celje, Slovenia; gasper.gantar@envita.si \\ 4 Laboratory for Mechatronics, Laboratory for Machining, University of Maribor, Faculty of Mechanical \\ Engineering, 2000 Maribor, Slovenia; shpetim.salihu@student.um.si (S.S.); uros.zuperl@um.si (U.Ž.) \\ 5 Environmental Protection College, 3320 Velenje, Slovenia \\ * Correspondence: miha.kovacic@store-steel.si
}

Citation: Kovačič, M.; Salihu, S.; Gantar, G.; Župerl, U. Modeling and Optimization of Steel Machinability with Genetic Programming: Industrial Study. Metals 2021, 11, 426. https://doi.org/10.3390/ met11030426

Academic Editor: Henrik Saxen

Received: 12 January 2021

Accepted: 28 February 2021

Published: 5 March 2021

Publisher's Note: MDPI stays neutral with regard to jurisdictional claims in published maps and institutional affiliations.

Copyright: (C) 2021 by the authors. Licensee MDPI, Basel, Switzerland. This article is an open access article distributed under the terms and conditions of the Creative Commons Attribution (CC BY) license (https:/ / creativecommons.org/licenses/by/ $4.0 /)$.

\begin{abstract}
In this paper, machinability influences from the start to end of final product production in a steel plant were analyzed, including chemical composition, deoxidizing agents and casting parameters, which drastically influence the macrostructure and segregation (i.e., chemical nonhomogeneity) of continuously cast and subsequently rolled material. The data (seven parameters from secondary metallurgy, four parameters from the casting process and the content of ten chemical elements) from the serial production of calcium-treated steel grades ( 254 batches of 25 different steel grades from January 2018 to March 2020) were used for predicting machinability. Machinability was determined based on ISO 3685:1993, where the machinability of each individual batch is represented as the cutting speed and the tool is worn out within fifteen minutes. For the prediction of these cutting speeds, linear regression and genetic programming were used. Out of 25 analyzed steel grades, $20 \mathrm{MnV} 6$ steel grade was the most problematic and also the most often produced. Out of 57 produced batches of 20MnVS6 steel, 23 batches had nonconforming machinability. Based on the modeling results, the steelmaking process was optimized. Consequently, 40 additional batches of 20MnV6 (from March 2020 to July 2020) were subsequently produced based on an optimized steelmaking process. In all 40 cases, the required machinability was achieved without changing other properties required by the customers.
\end{abstract}

Keywords: calcium-treated steel; steelmaking; secondary metallurgy; continuous casting; machinability; modeling; genetic programming; linear regression; optimization; industrial study

\section{Introduction}

Studies related to machinability and the steelmaking industry are typically oriented toward isolated aspects of a single material property or selected steel grades and do not include the possibilities of direct practical implementations (e.g., changes in steelmaking technology, casting process, heat treatment process) for serial production. Below, only a few studies dealing with material properties influences on machinability are presented.

The influences of individual chemical elements on the machinability of steels were elaborated decades ago [1-3]. Researchers mutually agree that silicon, sulfur, phosphorus, lead, tellurium, bismuth and antimony have a favorable effect on machinability. It must be emphasized that these elements are added to form inclusions with proper chemical composition, morphology, size and distribution; however, on the other hand, the influences of individual alloying elements that affect the steel matrix and consequently affect the mechanical properties are generally not known [4,5]. Accordingly, contemporary studies dealing with inclusion influences can be divided into those where the addition of inclusion- 
forming additives (e.g., alloys, elements) is analyzed $[4,6,7]$ and those where the influences of chemical composition, morphology, size and inclusion distribution are elaborated [8-10].

Brezočnik, Kovačič and Pšeničnik [6] modeled the machinability of several different calcium-treated steel grades based on reduction rate (i.e., final test bar diameter; bars were made from a billet square of $180 \mathrm{~mm}$ ) and the content of calcium, oxygen and sulfur. Aluminum-killed steel contains small aluminum silicate inclusions that have an abrasive effect. Accordingly, added calcium results in the occurrence of larger inclusions consisting of calcium-aluminum silicates with a less abrasive effect [3]. For machinability performance, ISO 3685:1993 [11] was used. The data of 140 subsequently cast batches, from serial production, were collected. Out of the selected 146 batches, only 123 achieved the required machinability. The mathematical model was able to predict machinability performance in $97.26 \%$ of all cases (out of 146 batches).

Desaigues, Lescalier, Bomont Arzur and Bomont [4] experimented with calcium treatment on non-calcium-treated steel. The machinability performance was determined using turning and drilling. Medium carbon steels (0.4-0.5\% of carbon) and alloyed steel were used in the research. All steel grades have been additionally treated with calcium. They found out that treating with calcium enhances steel machinability and also that tool material drastically affects the performance of calcium-treated steels.

Murakami, Toshiyuki Tomita and Shiraga [7] presented an attempt to develop a replacement of AISI12L14 steel containing lead. Based on calculations using phase diagrams, machinability and hot forging tests, machinability was increased with the formation of large sulfide inclusions, which were obtained by adding chromium and sulfur.

Chen, Bao, Wang, Cai, Wang and Zhao [12] proposed the replacement of manganese sulfide inclusions with boron nitride inclusions using $200 \mathrm{~kg}$ laboratory batches. The following steel grades were produced: 45S-BN, 45S, 45BN and C45. Based on theoretical calculations, the volume of boron nitride inclusions should be only $70 \%$ of manganese sulfide inclusions. At a two times lower sulfur content, machinability was predominant on steel with boron nitride inclusions.

Zanatta, Gomes, Bressan and Barbosa [13] analyzed the influences of manganese sulfide and titanium carbonitride inclusions on polishability. The results indicate that hard titanium carbonitride inclusions increase polishability; on the other hand, soft manganese sulfide inclusions are not influential, and they even worsen it with pinhole formation. The most important factors are the titanium content and size of titanium carbonitride inclusions.

Article [9] presents a practical implementation for improving the machinability of leaded steel with the use of different deoxidizing agents: carbon, manganese and tellurium. During the test production of batches, the oxygen level was kept from 80 to $120 \mathrm{ppm}$. Tellurium prevents the formation of hard silicon and aluminum inclusion and forms the deformable envelope of manganese sulfide inclusions, which prevents oxidation and the formation of less deformable sulfur oxide inclusions. Additionally, a low silicon content was achieved. Surface roughness and chip formation were analyzed, and the best performance was obtained using the batch with tellurium addition.

One of the papers about microstructure influences on chip formation [14] presents results of the turning of bainite and tempered martensite structure of $42 \mathrm{CrMo} 4$ steel, where chip morphology and cutting forces have been analyzed. For cutting force analysis, a changing cutting depth, speed and feeding were used. It was found out that the chip length did not depend on the microstructure and also that surface serration increased with the cutting speed.

The authors of this paper tried to analyze the machinability influences of 25 different calcium-treated steel grades. All the stages of production in the steel plant were included. Accordingly, data on chemical composition, deoxidizing agents and casting parameters, which drastically influence the macrostructure and segregation (i.e., chemical nonhomogeneity) $[15,16]$ of the continuously cast and subsequently rolled material, were collected. At the beginning of this paper, the problem regarding achieving machinability and data 
collection is presented, followed by a short explanation regarding machinability determination (based on ISO 3685:1993 [11]). Afterward, the machinability prediction using linear regression and genetic programming is presented, including the results of the steelmaking process optimization. Finally, conclusions are drawn and future work is emphasized.

\section{Materials and Methods}

Štore Steel Ltd. is one of the major flat spring steel producers in Europe, where more than 1000 steel grades with different chemical compositions are produced. In the same steel plant, more than 40 calcium-treated steel grades (different chemical compositions) are produced, representing up to $14 \%$ of total production. As mentioned, aluminumkilled steel contains small aluminum silicate inclusions, which have an abrasive effect. Accordingly, added calcium results in the occurrence of larger inclusions consisting of calcium-aluminum silicates with a less abrasive effect [3].

Production in this steel plant consists of melting scrap using an electric arc furnace, tapping, ladle treatment (i.e., secondary metallurgy) and continuous casting of the billets. After cooling, the billets are reheated and rolled in the rolling plant. The rolled bars can be additionally straightened, examined, cut, sawn, chamfered, drilled and peeled in the cold finishing plant.

The ladle treatment of the calcium-treated steel grades process starts with the tapping of the electric arc furnace with a capacity of 60 tons. During tapping, aluminum as a deoxidizing agent, lime as a slag-forming agent and alloys (e.g., nickel, ferrovanadium, ferromanganese, silicon manganese) are added into the ladle using automatic feeders while intensive argon stirring is used for melt homogenization. At the end of tapping, the argon stirring is decreased. Afterward, melt heating is conducted, the temperature is measured and the chemical composition is determined. After receiving the chemical analysis results (within $5 \mathrm{~min}$ ), based on the chemical composition requirements (technical delivery conditions), sulfur and other alloys are added. After alloying, argon stirring is performed again. After homogenization, the additional chemical composition is determined. Afterward, aluminum-cored wire is added, followed by the addition of calcium silicon or calcium-carbide-cored wire. The chemical composition is determined again. Based on technical delivery conditions, a sulfur-cored wire can also be added.

After reaching the proper casting temperature, the ladle is transferred to the rotating turret on a continuous caster above the tundish. Afterward, the melt is poured into the tundish after the sliding gate has been opened, with continuous casting being established throughout a casting system with an impact pod, stoppers, submerged entry nozzles and water-cooled copper molds. For the casting of the $180 \times 180 \mathrm{~mm}$ billets, a two-strand continuous caster with a $9 \mathrm{~m}$ radius is used. Solidification is conducted throughout primary cooling in the mold and secondary cooling using water sprays, which are divided into three zones. The billets are cooled down on the turnover cooling bed.

Before serial production, only one billet taken from the middle of the casting is reheated up to rolling temperature and rolled into round bars with a diameter of $95 \mathrm{~mm}$ using a roughing mill with a horizontal sliding reversible stand. It must be emphasized that before further rolling of the material (i.e., billets) for the customers, the machinability test according to ISO 3685:1993 "Tool-life testing with single-point turning tools" [11] is conducted. Based on the machinability test results, the batch can be reclassified as nonfree cutting steel grade and used for customers where machinability is not required within technical delivery conditions. The machinability tests are generally conducted within a week after the rolling process. Nonconform batches can be used for other customers and other applications, namely as standard steel grades without enhanced machinability.

According to ISO 3685:1993, the machine tool used for testing is equipped with a variable-speed spindle drive. The same cutting speed is maintained during workpiece diameter reduction (by successive cuts). Tool wear measurements are made at suitable intervals and recorded on the wear versus time measurement diagrams with at least five 
experimental points for each curve (Figure 1). The tool wear criteria for sintered carbide tools, which are used in Štore Steel Ltd., are (Figure 2):

- The maximum width of the flank wear land $\mathrm{VB}_{\mathrm{B}}$ max is equal to or more than $0.6 \mathrm{~mm}$;

- The average width of the flank wear land $\mathrm{VB}_{\mathrm{B}}$ is equal to or more than $0.3 \mathrm{~mm}$;

- tool failure;

- The depth of the crater KT is equal to or more than $0.18 \mathrm{~mm}$;

- The crater front distance reduces to a value of $\mathrm{KF}=0.02 \mathrm{~mm}$;

- The crater breaks through at the minor cutting edge (typically resulting in a poorly machined surface finish).

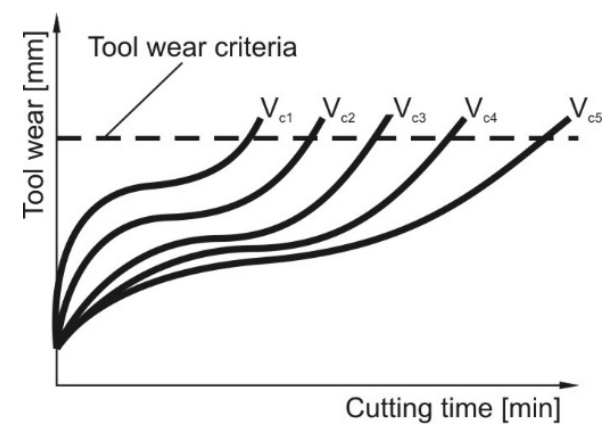

Figure 1. Development of tool wear for different cutting speeds.

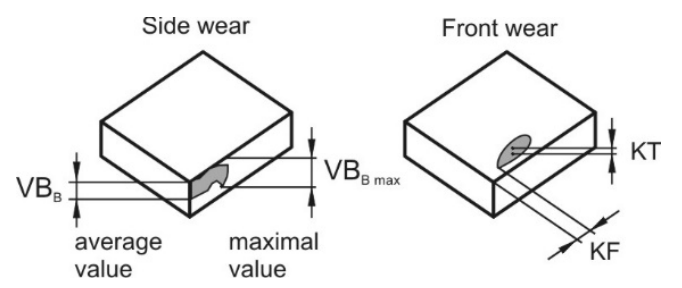

(a)

(b)

Figure 2. Maximum $\left(\mathrm{VB}_{\mathrm{B}} \max \right)$ and average $\left.\mathrm{VB}_{\mathrm{B}}\right)$ width of the flank wear land (a), the depth of the crater $(\mathrm{KT})$ and the crater front distance $(\mathrm{KF})(\mathbf{b})$.

Tool wear is determined using a profile projector for inspection of the tool geometry, a stopwatch for recording the cutting time, a microscope for measuring flank wear and a dial indicator for crater depth measurement. The results of the tool wear measurement at different cutting speeds can be easily presented in tool life versus cutting speed diagrams (Figure 3).

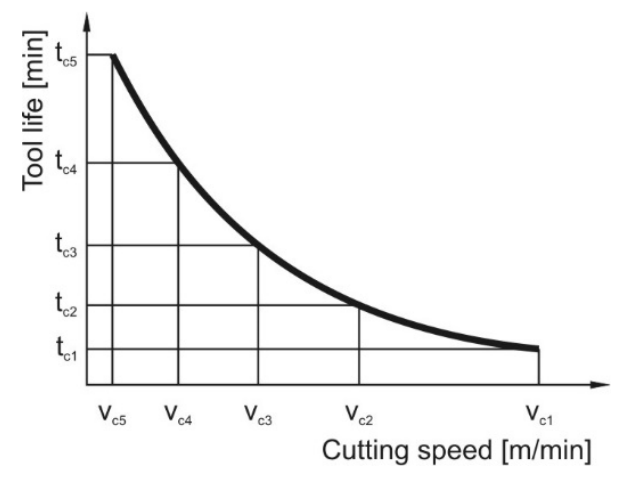

Figure 3. Tool life versus cutting speed diagram.

In certain circumstances, the tool life can be expressed in minutes of tool life at a single chosen speed. Based on the obtained diagrams of tool life versus cutting speed for 
each individual steel grade, the cutting speed where the tool wears out within 15 min was selected as a machinability criterion (Figure 4).

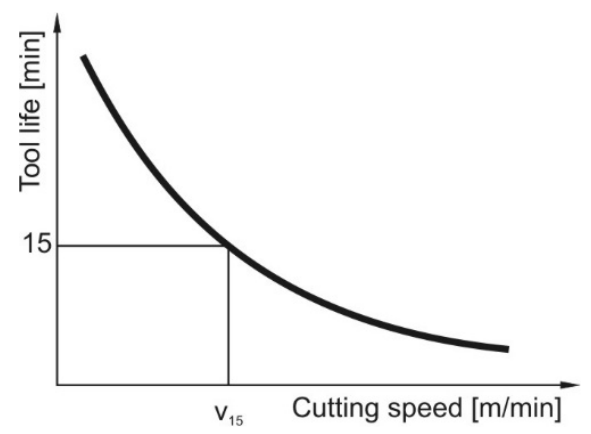

Figure 4. Cutting speed where the tool wears out within $15 \mathrm{~min}$.

For the additional machinability tests of the same steel grade material, the machinability test starts with machining using the previously obtained cutting speed where the tool wears out within $15 \mathrm{~min}$. Based on wear time, the actual cutting speed is calculated and compared to the cutting speed where the tool wears out within $15 \mathrm{~min}$ (Figure 5). If the actual cutting speed is higher or equal to the cutting speed where the tool wears out within $15 \mathrm{~min}$, the machinability of the tested material conforms.

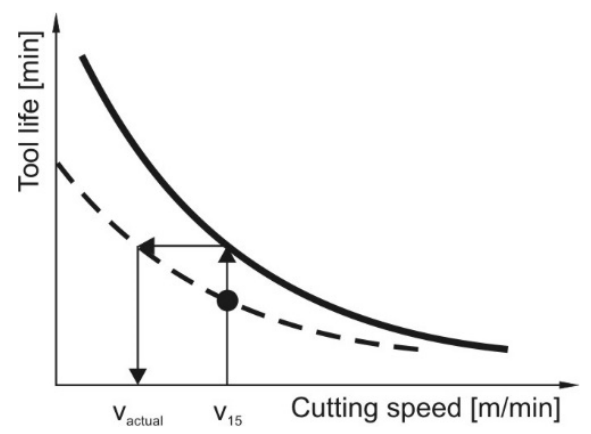

Figure 5. Determination of the actual cutting speed where the tool wears out within $15 \mathrm{~min}$.

In Štore, a diameter of $95 \mathrm{~mm}$ is always used for machinability tests. Prior to serial production, only one billet is rolled using a roughing mill with a horizontal sliding reversible stand. The rolled bars are cut into $0.5 \mathrm{~m}$ samples, which are machined. Before the test, $1.5 \mathrm{~mm}$ of the surface is removed. The samples are machined up to a $36 \mathrm{~mm}$ diameter with the feed $(0.25 \mathrm{~mm} / \mathrm{rev})$ and $5 \mathrm{~mm}$ cutting depth. The same cutting speed is obtained at every diameter change.

From January 2018 to March 2020, 254 batches of 25 different calcium-treated steel grades were cast consecutively. The following parameters were gathered:

1. Secondary metallurgy (i.e., ladle treatment):

- Calcium-carbide-cored wire $(\mathrm{m})$ used for the modification of aluminum silicate inclusions. According to the length of the calcium-carbide-cored wire addition, the inclusions of different types and morphology form, influencing the material properties and consequently the machinability.

- Ladle treatment time ( $\mathrm{min}$ ), including raffination, argon stirring, alloying, heating, slag forming, taking of samples and technological delays. Ladle treatment time is needed for melt homogenization (including temperature field) and also for purifying. Argon stirring causes inclusions to float up toward the slag, which can trap them.

- Calcium-silicon-cored wire $(\mathrm{m})$ used for the modification of aluminum silicate inclusions. Calcium silicon has the same function as calcium carbide to form proper inclusions. 
- Alloys added using automatic feeders:

- Ferrochromium with a low carbon content (kg).

- Ferrochromium with a high carbon content $(\mathrm{kg})$.

- Ferromanganese $(\mathrm{kg})$.

- Ferromolybdenum (kg).

- Ferrosilicon (kg).

- Ferrovanadium (kg).

- Nickel (kg).

- Sulfur-cored wire (m).

- Silicon manganese $(\mathrm{kg})$.

The alloys are used for achieving the required chemical composition.

2. Casting parameters influencing thermomechanical behavior, solidification and segregations (i.e., chemical nonhomogeneity) during casting:

- Average casting temperature $\left({ }^{\circ} \mathrm{C}\right)$. The casting temperature influences the thermal field in the mold, which influences heat removal and solidification. Due to the thermomechanical behavior of melt in the mold, the melt solidifies, gradually forming a layered nonhomogeneous structure. This structure influences the steel properties.

- Average difference between the input and output water temperature for each mold $\left({ }^{\circ} \mathrm{C}\right)$. This temperature difference is a measure of the efficiency of heat removal from the mold (i.e., primary cooling). The mold is cooled with water. The heating up of the cooling water flowing through the mold indicates the efficiency of heat removal, which influences the melt solidification.

- The average cooling water pressure in the first (directly below the mold) and the second zone of secondary cooling (bar). The melt primarily solidifies in the mold. After exiting the mold (mold is a $1 \mathrm{~m}$ long copper tube), the strand is cooled by water sprays, where water flux can be automatically set with varying water pressure. Consequently, water pressure is a measure of water spray nozzle clogging. In the event of water spray nozzle clogging, the pressure should be increased in order to achieve the same water flux, which enables cooling of cast billets. Secondary cooling directly influences the billets' macrostructure, including chemical composition, segregations (i.e., chemical nonhomogeneity) or material defect formation, which all influence the mechanical properties.

3. Chemical composition (\%). Content of carbon, silicon, manganese, sulfur, chromium, molybdenum, nickel, aluminum, vanadium and calcium. Chemical elements influence the microstructure and mechanical properties.

4. The cutting speed where the tool wears out within $15 \mathrm{~min}$ for individual batches ( $\mathrm{m} / \mathrm{min})$.

The minimal and maximal values of gathered parameters are presented in Table 1.

Table 1. Minimal and maximal values of the gathered parameters.

\begin{tabular}{cccc}
\hline Parameter & Label & Minimum & Maximum \\
\hline Calcium-carbide-cored wire $(\mathrm{m})$ & CAC2 & 0 & 215 \\
Ladle treatment time (min) & TIMEL & 24 & 100 \\
Calcium-silicon-cored wire $(\mathrm{m})$ & CASI & 0 & 340 \\
Ferrochromium with low carbon content $(\mathrm{kg})$ & FECRA & 0 & 597 \\
\hline
\end{tabular}


Table 1. Cont.

\begin{tabular}{|c|c|c|c|}
\hline Parameter & Label & Minimum & Maximum \\
\hline Ferrochromium with high carbon content (kg) & FECRC & 0 & 1578 \\
\hline Ferromanganese $(\mathrm{kg})$ & FEMN & 0 & 1004 \\
\hline Ferromolybdenum (kg) & FEMO & 0 & 274 \\
\hline Ferrosilicon $(\mathrm{kg})$ & FESI & 0 & 337 \\
\hline Ferrovanadium (kg) & FEV & 0 & 106 \\
\hline Nickel (kg) & NIKG & 0 & 1001 \\
\hline Sulfur-cored wire (m) & SM & 0 & 110 \\
\hline Silicon manganese $(\mathrm{kg})$ & SIMN & 0 & 1199 \\
\hline Average casting temperature $\left({ }^{\circ} \mathrm{C}\right)$ & TEMPC & 1516 & 1564 \\
\hline $\begin{array}{l}\text { Average difference between input and output } \\
\text { water temperature for each mold }\left({ }^{\circ} \mathrm{C}\right)\end{array}$ & DELTATEMP & 4.66 & 8.78 \\
\hline $\begin{array}{l}\text { The average cooling water pressure in the first } \\
\text { zone of secondary cooling (bar) }\end{array}$ & P1 & 2.61 & 6.68 \\
\hline $\begin{array}{l}\text { The average cooling water pressure in the } \\
\text { second zone of secondary cooling (bar) }\end{array}$ & P2 & 1.53 & 4.93 \\
\hline Carbon content $(\%)$ & $\mathrm{C}$ & 0.08 & 0.55 \\
\hline Silicon content $(\%)$ & SI & 0.02 & 0.45 \\
\hline Manganese content $(\%)$ & $\mathrm{MN}$ & 0.34 & 1.59 \\
\hline Sulfur content $(\%)$ & $S$ & 0.013 & 0.059 \\
\hline Chromium content $(\%)$ & CR & 0.06 & 2 \\
\hline Molybdenum content (\%) & $\mathrm{MO}$ & 0.01 & 0.37 \\
\hline Nickel content $(\%)$ & NI & 0.05 & 1.96 \\
\hline Aluminum content $(\%)$ & $\mathrm{AL}$ & 0.011 & 0.031 \\
\hline Vanadium content $(\%)$ & $\mathrm{V}$ & 0 & 0.14 \\
\hline Calcium content (\%) & CA & 0.0011 & 0.005 \\
\hline $\begin{array}{l}\text { The cutting speed where the tool wears out } \\
\text { within } 15 \text { min forindividual batches }(\mathrm{m})\end{array}$ & $V_{c}, 15 \mathrm{~min}$ & 210 & 450 \\
\hline
\end{tabular}

\section{Modeling of Cutting Speed Where the Tool Wears Out within 15 min}

On the basis of the collected data (Table 1), the prediction of cutting speed where the tool wears out within $15 \mathrm{~min}$ for individual batches (calculated based on actual tool wear time and reference cutting speed where the tool wears out within $15 \mathrm{~min}$ for individual batches), was conducted using linear regression and genetic programming. For the fitness function, the average deviation between the predicted and experimental data was selected. It is defined as:

$$
\Delta=\frac{\sum_{i=1}^{n}\left|Q_{i}-Q^{\prime}{ }_{i}\right|}{n},
$$

where $n$ is the size of the monitored data, and $Q_{i}^{\prime}$ and $Q_{i}$ are the actual and predicted actual cutting speeds, respectively.

\subsection{Modeling of Cutting Speed Where the Tool Wears Out within 15 min Using Linear Regression}

On the basis of the linear regression results, it is possible to conclude that the model significantly predicts the actual cutting speed ( $p<0.05$, ANOVA), and $86.60 \%$ of total variances can be explained by independent variable variances (R-square). Significantly influential parameters $(p>0.05)$ are ferrosilicon (FESI), ferrovanadium (FEV), sulfur-cored wire (SM), the average cooling water pressure in the first zone of secondary cooling (P1), carbon $(\mathrm{C})$ and manganese content $(\mathrm{MN})$.

The analysis of variance (ANOVA) results are presented in the next table (Table 2). 
Table 2. ANOVA results.

\begin{tabular}{|c|c|c|c|c|c|c|}
\hline \multicolumn{7}{|c|}{ ANOVA(b) } \\
\hline Model & & $\begin{array}{l}\text { Sum of } \\
\text { Squares }\end{array}$ & df & $\begin{array}{l}\text { Mean } \\
\text { Square }\end{array}$ & $\mathbf{F}$ & Significance \\
\hline \multirow[t]{3}{*}{1} & Regression & $1,031,300$ & 26 & $39,665.39$ & 72.373 & 0.000 \\
\hline & Residual & $124,411.5$ & 227 & 548.068 & & \\
\hline & Total & $1,155,712$ & 253 & & & \\
\hline
\end{tabular}

The linear regression model is:

$$
\begin{gathered}
v_{c, 15 \min }=-0.186 \cdot C A C 2+0.014 \cdot T I M E L+0.072 \cdot C A S I+0.044 \cdot F E C R A-0.036 \cdot F E C R C-0.029 \cdot F E M N \\
-0.355 \cdot F E M O-0.147 \cdot F E S I-0.664 \cdot F E V+0.099 \cdot N I K G-0.25 \cdot S M-0.009 \cdot S I M N+7.592 \cdot T E M P C+ \\
3.51 \cdot D E L T A T E M P+3.845 \cdot P 1+3.51 \cdot P 2-182.115 \cdot C+89.805 \cdot S I-49.304 \cdot M N-1.626 \cdot S- \\
27.224 \cdot C R-236.437 \cdot M O+6.831 \cdot N I-0.46 \cdot A L-2.299 \cdot V-6.967 \cdot C A-115.811
\end{gathered}
$$

The average deviation from experimental data is $3.88 \%$.

\subsection{Modeling of Cutting Speed Where the Tool Wears Out within 15 min Using Genetic Programming}

In genetic programming, which is one of the most general evolutionary optimization methods, the organisms that undergo adaptation are in fact mathematical expressions (models). These models consist of the selected function (e.g., basic arithmetical functions) and terminal genes (e.g., independent input parameters and random floating-point constants). Typical function genes are: addition $(+)$, subtraction $(-)$, multiplication $(\times)$, division $(/)$ and terminal genes (e.g., $x, y, z$ ). Random computer programs for calculating various forms and lengths are generated by means of the selected genes at the beginning of the simulated evolution. The varying of the computer programs is carried out by means of genetic operations (e.g., crossover, mutation) during several iterations, called generations. After the completion of the variation of the computer programs, a new generation is obtained. Each result obtained from an individual program from a generation is evaluated in comparison with the experimental data. The process of changing and evaluating organisms is repeated until the termination criterion of the process is fulfilled.

An in-house genetic programming system, programmed using AutoLISP, which is integrated into AutoCAD (i.e., commercial computer-aided design software), was used [15,17-20]. Its settings were:

- $\quad$ Size of the population of organisms: 1000;

- Maximum number of generations: 100;

- Reproduction probability: 0.4;

- Crossover probability: 0.6;

- Maximum permissible depth in the creation of the population: 30;

- Maximum permissible depth after the operation of crossover of two organisms: 30;

- Smallest permissible depth of organisms in generating new organisms: 2 .

Genetic operations of reproduction and crossover were used. For the selection of organisms, the tournament method with a tournament size of seven was used.

The AutoLISP-based in-house genetic programming system was run 100 times in order to develop 100 independent civilizations. Each run lasted approximately $46 \mathrm{~min}$ and $53 \mathrm{~s}$ on an i7 Intel processor and $8 \mathrm{~GB}$ of RAM. The best mathematical model for prediction of cutting speed where the tool wears out within 15 min obtained from 100 runs of genetic programming system is: 


$$
\begin{aligned}
& v_{c, 15 \min }=120.079 \cdot+1002.16 \cdot \mathrm{AL}-197.792 \cdot \mathrm{C}-106.207 \cdot \mathrm{CA}+0.113 \cdot \mathrm{CASI}-30.542 \cdot \mathrm{CR}- \\
& \text { 2.081 DELTATEMP + 0.016.FECRA }-0.037 \cdot \mathrm{FECRC}+0.034 \cdot \mathrm{FEMN}-0.185 \cdot \mathrm{FEMO}- \\
& \text { 0.037.FESI }+0.217 \cdot \mathrm{FEV}-72.763 \cdot \mathrm{Mn}-331.951 \cdot \mathrm{MO}+43.435 \cdot \mathrm{NI}+0.04 \cdot \mathrm{NIKG}+6.044 \cdot \mathrm{P} 1-1.383 \cdot \mathrm{P} 2- \\
& \text { 1341.1.S + 69.753.SI + 0.064·SIMN }-0.115 \cdot \mathrm{SM}+0.252 \cdot \mathrm{TEMPC}-0.175 \cdot \mathrm{TIMEL} \\
& +0.029 \cdot(1002.16 \cdot \mathrm{AL}-197.792 \cdot \mathrm{C}+\mathrm{CA} \cdot \mathrm{CAC} 2-30.542 \cdot \mathrm{CR}-331.951 \cdot \mathrm{MO}+ \\
& 43.435 \cdot \mathrm{NI}+6.044 \cdot \mathrm{P} 1-1.383 \cdot \mathrm{P} 2-1341.1 \cdot \mathrm{S}+0.064 \cdot \mathrm{SIMN}+(\mathrm{MO} / \mathrm{FESI}-\mathrm{FESI} \cdot \mathrm{SIMN}) / \\
& (-2.081-\mathrm{P} 2+\mathrm{SIMN})+0.252 \cdot \mathrm{TEMPC}-(8.69565 \cdot(-193.829+0.281 \cdot \mathrm{FEV}-2.081 \cdot \mathrm{FEV} \cdot \mathrm{MO}+ \\
& 0.04 \cdot \mathrm{NIKG}+6.044 \cdot \mathrm{P} 1-1.383 \cdot \mathrm{P} 2+69.753 \cdot \mathrm{SI}+0.064 \cdot \mathrm{SIMN}+ \\
& \text { DELTATEMP·FECRA·Mn·SIMN }+(0.04 \cdot \mathrm{FECRC} \cdot \mathrm{MO} 2 \cdot \mathrm{NIKG} \cdot(-\mathrm{P} 2+2 \cdot \mathrm{SIMN})) / \\
& (\mathrm{NI} \cdot(\mathrm{MO} / \mathrm{FESI}-\mathrm{FESI} \cdot \mathrm{SIMN}))-0.115 \cdot \mathrm{SM}-(8.69565 \cdot(-\mathrm{SI} \cdot \mathrm{SIMN}+(\text { FECRC } \cdot \mathrm{FESI} \cdot \mathrm{MO} 2 \cdot(-\mathrm{P} 2+2 \cdot \mathrm{SIMN})) \\
& /(\mathrm{NI} \cdot(\mathrm{MO} / \mathrm{FESI}-\mathrm{FESI} \cdot \mathrm{SIMN})))) /((\mathrm{CASI}+\mathrm{FECRC}) \cdot(-\mathrm{P} 2+\mathrm{SIMN}+6.044 \cdot \mathrm{P} 1 \\
& -1.383 \cdot \mathrm{FEV} \cdot \mathrm{P} 2-1.081 \cdot \mathrm{SIMN}+0.252 \cdot \mathrm{DELTATEMP} \cdot \mathrm{FEV} \cdot \mathrm{P} 2 \cdot \\
& (-197.792 \cdot \mathrm{C}-2.081 \cdot \mathrm{DELTATEMP}+\mathrm{C} \cdot \mathrm{FECRA}-72.763 \cdot \mathrm{Mn}-1341.1 \cdot \mathrm{S}+69.753 \cdot \mathrm{SI}+0.252 \cdot \mathrm{TEMPC}))) \\
& +(0.252 \cdot \mathrm{NI} \cdot \mathrm{SIMN}) /(\mathrm{FECRC} \cdot \mathrm{MO} \cdot \mathrm{TEMPC})+0.252 \cdot \mathrm{TEMPC} \\
& \text { +SM }(-228.334 \cdot \mathrm{C}-0.115 \cdot \mathrm{CASI}-72.763 \cdot \mathrm{Mn}-331.951 \cdot \mathrm{MO}+6.044 \cdot \mathrm{P} 1-1.383 \cdot \mathrm{FEV} \cdot \mathrm{P} 2-1341.1 \cdot \mathrm{S}-2.081 \cdot \mathrm{SM}+ \\
& \text { 0.252 } \cdot \mathrm{TEMPC}+\mathrm{SIMN} \cdot(1002.16 \cdot \mathrm{AL}+69.753 \cdot \mathrm{CA}-760.977 \cdot \mathrm{V}))+\mathrm{SIMN} \cdot(3093.35 \cdot-395.584 \cdot \mathrm{C} \\
& +137.425 \cdot \mathrm{CA}-30.542 \cdot \mathrm{CR}+0.064 \cdot \mathrm{FECRC}-72.763 \cdot \mathrm{FEV}-72.763 \cdot \mathrm{Mn}-995.853 \cdot \mathrm{MO}+1002.16 \cdot \mathrm{NI} \\
& +6.044 \cdot \mathrm{P} 1-1.383 \cdot \mathrm{P} 2+43.435 \cdot \mathrm{NI} \cdot \mathrm{P} 2-1341.1 \cdot \mathrm{S}+0.252 \cdot \mathrm{P} 2 \cdot \mathrm{SIMN}+0.252 \cdot \mathrm{TEMPC}-2285.01 \cdot \mathrm{V})+ \\
& \mathrm{P} 1 \cdot(1045.64 \cdot-197.792 \cdot \mathrm{C}+69.753 \cdot \mathrm{FEMO}-72.763 \cdot \mathrm{Mn}-331.951 \cdot \mathrm{MO}-2.081 \cdot \mathrm{NIKG} \\
& +6.044 \cdot \mathrm{P} 1-1.383 \cdot \mathrm{P} 2+6.044 \cdot \mathrm{FEV} \cdot \mathrm{P} 2-1341.1 \cdot \mathrm{S}+0.064 \cdot \mathrm{SIMN}-0.115 \cdot \mathrm{SM}+0.252 \cdot \mathrm{TEMPC} \\
& -760.977 \cdot \mathrm{V})-1.383 \cdot \mathrm{V})) /((\mathrm{C} \cdot \mathrm{CASI}+\mathrm{FECRC}) \cdot(-\mathrm{P} 2+2 \cdot \mathrm{SIMN}))-760.977 \cdot \mathrm{V})-760.977 \cdot \mathrm{V}
\end{aligned}
$$

The average deviation from the experimental data is $3.78 \%$.

\section{Optimization of Steel Making Process for the 20MnV6 Steel Grade}

The 20MnV6 steel grade has the biggest production share among calcium-treated steel grades in Štore. A total of 57 20MnV6 batches out of 254 batches of calcium-treated steel were produced in the period from January 2018 to March 2020. Of 23 batches of 20MnV6 (out of 57) (40.35\%), the cutting speed where the tool wears out within 15 min was lower than the reference cutting speed obtained according to ISO-3685:1993 (i.e., the required machinability was not achieved).

The linear regression model and the genetic programming model already-developed were used for the prediction of the cutting speed where the tool wears out within 15 min for 57 20MnV6 batches. The deviations between the experimental data and linear regression model and between the experimental data and genetic programming model are $5.72 \%$ and $4.94 \%$, respectively. Figure 6 shows the calculated influences of individual parameters on the cutting speed where the tool wears out within 15 min using the linear regression model (Equation (2)) while separately changing individual parameters within the individual parameter range.

Ten best influential parameters are ferrosilicon (FESI), ferromanganese (FEMN), ferrovanadium (FEV), calcium silicon (CASI), sulfur-cored wire (SM), casting temperature (TEMPC), silicomanganese (SIMN), silicon content (SI), the average cooling water pressure in the second zone of secondary cooling (P2) and the average difference between input and output water temperature for each mold (DELTATEMP). Figure 7 shows the calculated influences of individual parameters on the cutting speed where the tool wears out within 15 min using the linear regression model (Equation (3)) while separately changing individual parameters within the individual parameter range. 


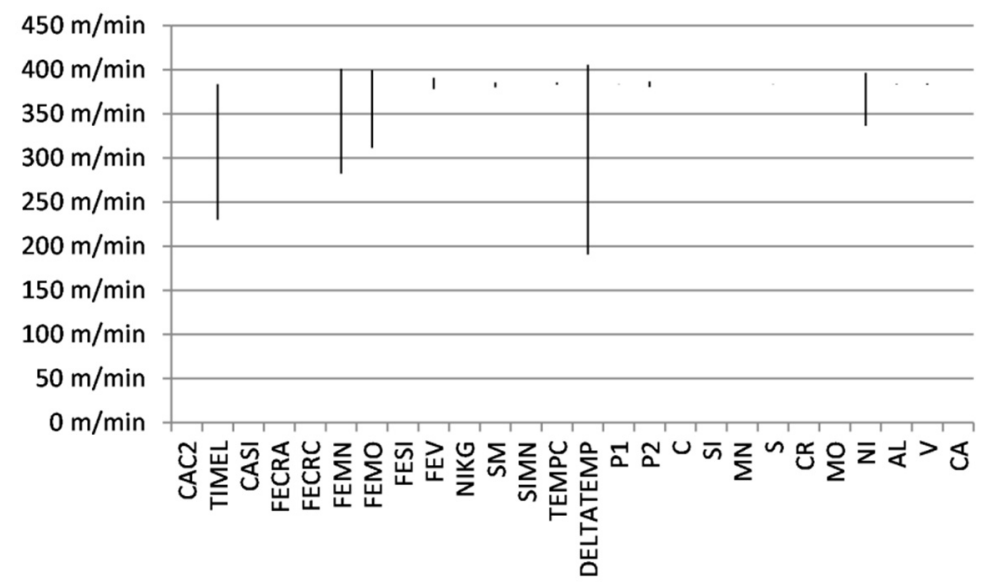

Figure 6. Calculated influences of individual parameters on cutting speed where the tool wears out within 15 min using the linear regression model (Equation (1)).

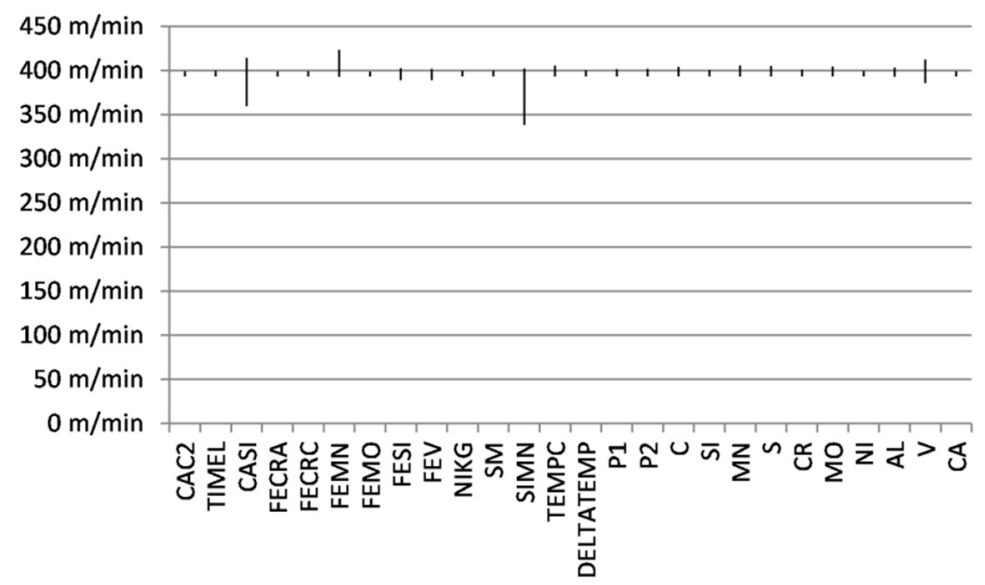

Figure 7. Calculated influences of individual parameters on cutting speed where the tool wears out within 15 min using the genetic programming model (Equation (2)).

The ten best influential parameters are calcium silicon (CASI), ferromanganese (FEMN) and silicomanganese (SIMN), similarly to the linear regression model. Consequently, on the basis of the modeling results, the following changes were made during the ladle treatment of 20MnV6 steel from March 2020 to July 2020. Ferromanganese and ferrosilicon were partly replaced with silicon manganese. On the other hand, the addition of sulfur-cored wire was increased. Additionally, the originally installed nozzles, supplied by the producer of continuous caster and prone to clogging, were replaced with self-cleaning water spray nozzles at secondary cooling.

The role of other influential parameters, which were not changed, should be clarified. Based on the calculated influences of vanadium content and ferrovanadium addition, it is possible to conclude that at the required melt vanadium content (according to the technical delivery conditions), ferrovanadium is added during the ladle treatment (i.e., secondary metallurgy) based on initial scrap vanadium content, which varies greatly. Casting temperature and ladle treatment time depend on a number of sequences (i.e., ordered quantity) and production pace, dependent on peak electricity hours. Accordingly, practical changes related to the casting temperature and ladle treatment time are not possible. Immediately after the ladle treatment, the ladle is transferred to a rotating turret on a continuous caster above the tundish, where the casting process is established. The average difference between input and output water temperature for each mold is a measure of the efficiency of heat removal from the mold (i.e., primary cooling), which actually establishes the temperature field of molten steel in the mold. This temperature field is later influenced by water sprays during secondary cooling. The temperature field influences 
the solidification process, where melt solidifies gradually, forming layered and chemically nonhomogenous cast structure. Based on modeling results, the chemical composition variations (within technical delivery conditions) do not affect machinability.

After the implementation of changes into production, ferromanganese and ferrosilicon statistically significantly decreased by $56.68 \%(t$-test, $p<0.05)$ and $31.77 \%(t$-test, $p<0.05)$, respectively. Statistically significantly, the addition of sulfur-cored wire was increased by $51.41 \%$ ( $t$-test, $p<0.05)$. Additionally, the average water pressure statistically significantly dropped from an average of 3.8 to 2.37 bar ( $t$-test, $p<0.05$ ). The pressure of the secondary cooling system is automatically regulated during casting according to preset water flux.

It must be emphasized that microcleanliness before and after changes in production was also analyzed. According to technical delivery conditions $\mathrm{K} 3$ values, taking into account only globular oxides, determined according to DIN 50 602, were required. Micro cleanliness has not been changed statistically significantly after changing the steelmaking process $(t$-test, $p<0.05)$.

For all the 23 additional 20MnV6 batches, produced within the period from March 2020 to July 2020, the machinability conformed. The same was confirmed by calculation using both the linear regression model and genetic programming model. The deviations between experimental data and linear regression model and between experimental data and genetic programming model are $4.51 \%$ and $2.61 \%$, respectively.

\section{Conclusions}

The data (7 parameters from secondary metallurgy, 4 parameters from the casting process and the content of 10 chemical elements) from serial production of calcium-treated steel grades (254 batches of 25 different steel grades from January 2018 to March 2020) were used for predicting machinability. Machinability was determined based on ISO 3685:1993. Based on the existing, determined tool life, cutting speed curves (for individual steel grades) and the actual toll life of the individual batch, the cutting speeds where the tool wears out within 15 min were calculated.

For the prediction of cutting speed where the tool wears out within $15 \mathrm{~min}$, linear regression and genetic programming were used. The deviations between experimental data and the linear regression model and between experimental data and genetic programming model are $5.72 \%$ and $4.94 \%$, respectively.

Based on the modeling results, the steelmaking process was optimized for one of the most problematic ( $40.35 \%$ of batches with nonconforming machinability) and most often produced steel grades, 20MnV6 (57 batches out of 254 batches). All 57 20MnV6 batches were produced in the period from January 2018 to March 2020. In 23 batches of 20MnV6 ( $40.35 \%$ out of 57 ), the actual cutting speed where the tool wears out within 15 min was lower than the reference cutting speed where the tool wears out within $15 \mathrm{~min}$, obtained according to ISO-3685:1993 (i.e., required machinability was not achieved).

Consequently, on the basis of the modeling results, the following changes were made during the ladle treatment of 20MnV6 steel from March 2020 to July 2020. Ferromanganese and ferrosilicon were partly replaced with silicon manganese. On the other hand, the addition of sulfur-cored wire was increased. Additionally, originally installed nozzles, which were prone to clogging, supplied by the producer of the continuous caster, were replaced with self-cleaning water spray nozzles at secondary cooling.

After the implementation of changes into production, the ferromanganese and ferrosilicon content statistically significantly decreased by $56.68 \%(t$-test, $p<0.05)$ and $31.77 \%$ ( $t$-test, $p<0.05)$, respectively. Statistically significantly, the addition of sulfur-cored wire was increased by $51.41 \%$ ( $t$-test, $p<0.05)$. Additionally, the average water pressure statistically significantly dropped from an average of 3.8 to 2.37 bar $(t$-test, $p<0.05)$. The pressure of the secondary cooling system is automatically regulated during casting according to a pre-set water flux.

It must be emphasized that microcleanliness was not changed statistically significantly after changing the steelmaking process $(t$-test, $p<0.05)$. 
In all 23 additional 20MnV6 batches produced within the period from March 2020 to July 2020, the machinability was conforming. The same was confirmed by a calculation using both the linear regression and genetic programming models. The deviations between the experimental data and linear regression model and between the experimental data and genetic programming model are $4.51 \%$ and $2.61 \%$, respectively.

In the future, the optimization of other steel grades will be considered, with a focus on improving microcleanliness and the reduction of the addition of deoxidizing agents and alloys.

Author Contributions: Conceptualization, M.K. and U.Ž., Data curation, M.K., Formal analysis, S.S., Gašper Gantar and U.Ž., Investigation, M.K., S.S. and U.Ž., Methodology, M.K. and U.Ž., Project administration, G.G., Software, M.K., Writing—original draft, M.K. and U.Ž., Writing-review and editing, S.S. and G.G. All authors have read and agreed to the published version of the manuscript.

Funding: This research received no external funding.

Data Availability Statement: Not applicable.

Conflicts of Interest: The authors declare no conflict of interest.

\section{References}

1. Ernst, H. Machining of Metals; American Society for Metals: Materials Park Campus, Russell Township: Geauga County, OH, USA, 1938; p. 177.

2. Stephenson, D.A.; Agapiou, J.S. Metal Cutting Theory and Practice; CRC Press: Boca Raton, FL, USA, 1997 ; ISBN 9780585139210.

3. Boulger, F.W. Machinability of Steels. In Properties and Selection: Irons, Steels, and High-Performance Alloys; ASM International, Materials Park Campus, Rusell Township: Geauga County, OH, USA, 1990; pp. 591-602.

4. Desaigues, J.-E.; Lescalier, C.; Bomont Arzur, A.; Bomont, O. High Strength Steel solutions for automotive parts: State of the art of machinability enhancement and further developments. In Proceedings of the Tenth International Conference on High Speed Machining, Darmstadt, Germany, 26-27 September 2013; pp. 270-277.

5. Kovach, C.W.; Moskowitz, A. Part X October 1969_Papers_Effects of Manganese and Sulfur on the Machinability of Martensitic Stainless Steels; The American Institute of Mining, Metalurgical and Petroleum Engineers, 12999 East Adam Aircraft Circle: Englewood, NJ, USA, 1970.

6. Brezočnik, M.; Kovačič, M.; Pšeničnik, M. Prediction of steel machinability by genetic programming. J. Achiev. Mater. Manuf. Eng. 2006, 16, 107-113.

7. Murakami, T.; Tomita, K.; Shiraga, T. Development of Free Cutting Steel without Lead Addition to Replace AISI12L14. JFE Tech. Rep. 2010, 15, 10-16.

8. Ånmark, N.; Karasev, A.; Jönsson, P. The Effect of Different Non-Metallic Inclusions on the Machinability of Steels. Materials 2015, 8, 751-783. [CrossRef] [PubMed]

9. Sathyamurthy, P.; Vetrivelmurugan, R.; Sooryaprakash, J. Improving the machinability of leaded free cutting steel through process optimization. IOP Conf. Ser. Mater. Sci. Eng. 2018, 314, 012019. [CrossRef]

10. Costa e Silva, A.L.V. da The effects of non-metallic inclusions on properties relevant to the performance of steel in structural and mechanical applications. J. Mater. Res. Technol. 2019, 8, 2408-2422. [CrossRef]

11. International Organization for Standardization. ISO 3685:1993, Tool-Life Testing with Single-Point Turning Tools. Available online: https: / / www.iso.org/standard/9151.html (accessed on 1 March 2021).

12. Chen, Y.; Bao, Y.; Wang, M.; Cai, X.; Wang, L.; Zhao, L. Superior machinability of steel enhanced with BN and MnS particles. Int. J. Miner. Metall. Mater. 2016, 23, 276-282. [CrossRef]

13. Zanatta, A.M.; Gomes, J.D.O.; Bressan, J.D.; Barbosa, C.A. Influence of Hard and Soft Inclusions on the Machinability and Polishability of VP100 Mold Steel. Adv. Mater. Res. 2011, 223, 464-472. [CrossRef]

14. Haddad, F.; Lescalier, C.; Desaigues, J.-E.; Bomont-Arzur, A.; Bomont, O. Metallurgical Analysis of Chip Forming Process when Machining High Strength Bainitic Steels. J. Manuf. Mater. Process. 2019, 3, 10. [CrossRef]

15. Kovačič, M.; Novak, D. Prediction of the chemical non-homogeneity of 30MnVS6 billets with genetic programming. Mater. Tehnol. 2016, 50, 69-74. [CrossRef]

16. Hutny, A.M.; Warzecha, M.; Derda, W.; Wieczorek, P. Segregation of Elements in Continuous Cast Carbon Steel Billets Designated for Long Products. Arch. Metall. Mater. 2016, 61, 2037-2042. [CrossRef]

17. Kovačič, M.; Župerl, U. Genetic programming in the steelmaking industry. Genet. Program. Evolvable Mach. 2020, 21, 99-128. [CrossRef]

18. Kovačič, M.; Šarler, B. Genetic programming prediction of the natural gas consumption in a steel plant. Energy 2014, 66. [CrossRef] 
19. Stopar, K.; Kovačič, M.; Kitak, P.; Pihler, J. Electric arc modeling of the EAF using differential evolution algorithm. Mater. Manuf. Process. 2017, 32, 1189-1200. [CrossRef]

20. Kovačič, M. Modeling of Total Decarburization of Spring Steel with Genetic Programming. Mater. Manuf. Process. 2015, 30, 434-443. [CrossRef] 